\title{
Procesuālās ekonomijas princips kriminālprocesā
}

\author{
Dr. iur. Sandra Kaija \\ Rìgas Stradina universitāte, Juridiskā fakultāte, \\ Tiesību zinātṇu katedra, Latvija
}

\section{Kopsavilkums}

Rakstā autore izskata jautājumus par procesuāās ekonomijas principa izpausmi kriminālprocesā. Pētījumā tiek skatìtas kriminālprocesa ekonomijas, efektivitātes un iedarbīguma problēmas. Tiek piedāvāts ne tikai pilnveidot pašreizējo tiesisko bāzi, bet arī ievērot jau esošos tiesību aktus, amatpersonām un tiesām pieṇemot objektīvus lēmumus kriminālprocesos.

Atslēgvārdi: kriminālprocess, procesuālā ekonomija.

\section{levads}

Kriminālprocesa būtību un attīstības perspektīvas lielā mērā nosaka kriminālprocesa principos definētās konceptuālās idejas. Šo ideju izstrāde un adaptācija, piemērojot prakses vajadzībām, ir kriminālprocesa zinātnes svarīgākais uzdevums. Kriminālprocesa likuma (turpmāk arī KPL) piemērošanas prakse, vērtējot arī kriminālprocesa normu izmaiṇu kontekstā, parāda, ka principu sistēma, kas nostiprināta KPL 2. nodal̦ā, nevar tikt izskatīta par galējo teorētisko un praktisko sasniegumu punktu. Kriminālprocesa principu sistēma izpētei un pilnveidei joprojām ir atvērta, ko apliecina arī Latvijā veiktie pētījumi, piemēram, par kriminālprocesuālo imunitāti kā kriminālprocesa principu [6].

Raksta mērḳis ir izpētìt dažus procesuālās ekonomijas aspektus kriminālprocesā, kā arī tās realizācijas iespējas tiesību jaunrades un tiesībpiemērošanas sfērā, kā arī raisīt diskusiju par šā principa ieviešanas nepieciešamību Kriminālprocesa likumā.

Rakstā galvenokārt izmantotas šādas izpētes metodes: analītiskā, vēsturiskā un salīdzinošā. 


\section{Svarīgākās atziṇas teorijā un praksē}

Viena no galvenajām idejām, par ko būtu nepieciešams diskutēt, ir procesuālās ekonomijas princips, kas nav iekḷauts kriminālprocesa pamatrincipu sistēmā. Praksē šis princips ir ḷoti aktuāls un pieprasīts. Gandrīz desmit gadu KPL piemērošanas prakse ir parādījusi, ka vienkāršota un efektīva kriminālprocesa nepieciešamība atrodas sarežğîtā mijiedarbỉbā: ne viss "vienkāršots" var tikt atzìts par ekonomisku, savukārt "sarežgìits" - par izšḳērdīgu.

Procesuālās ekonomijas ideja neaprobežojas tikai ar procesa ātrumu un vienkāršošanu. Mūsdienu kriminālprocesa tiesības akcentē arī citus kriminālprocesa racionalitātes aspektus. Tie parādās arī terminologiskās novitātēs, piemēram, "saprātīgā termiṇa" jēdzienā. Nav mazsvarīgi, ka tas ir ieklauts kriminālprocesa pamatprincipu sistēmā (KPL 14. pantā).

Šobrīd vairs nav apšaubāms, ka jurisprudencē ir ieviests procesuālās ekonomijas princips. Tas tiek izmantots dažādās tiesību apakšnozarēs. Piemēram, viens no Administratīvā procesa likuma 191. panta pirmās daḷas 2. punkta mērḳiem ir ìstenot procesuālās ekonomijas principu, kas paredz arī iespēju robežās izvairīties no atkārtotu procesuālo darbību veikšanas, kuras izdarītas jau līdz šim, tādējādi samazinot arī izlietoto resursu apjomu, kā arī administratīvā procesa dalībnieku un tiesas laika patēriṇu [2]. Arī likuma "Par tiesu varu" 28. pants paredz procesuālās ekonomijas principu, nosakot, ka tiesnesis izspriež lietu tik ātri, cik vien iespējams, un ka personai, kas piedalās lietā, jāievēro likuma vai tiesas noteiktie procesuālie termiṇi.

Šim jautājumam vairākkārt ir pievērsusies arī Satversmes tiesa, norādot, ka procesuālās ekonomijas princips nav pašmērḳis un šajā gadỉjumā kalpo vēl svarīgākam principam - tiesībām uz taisnīgu tiesu [3]. Procesuālā ekonomija, no vienas puses, un procesuālo tiesību vienlïdzība, no otras, ir Satversmes 92. panta satura elementi, kuriem jāatrodas saprātīgā līdzsvarā. Satversmes tiesai šajā gadījumā ir jāizvērtē, vai sabiedrības ieguvums no procesuālās ekonomijas nenonāk nesamērīgā pretrunā ar pušu procesuālo tiesību vienlīdzību [4]. Ideja par procesuālo ekonomiju ir aktuāla visā kriminālprocesa attīstības vēsturē. Faktiski nepieciešamība pēc procesuālās ekonomijas ir radusies vienlaikus ar procesuālo formu. Ekonomijas ideja ir jebkuras formas elements, jo pati procesuāā forma ir kriminālprocesuālās darbības ekonomiskākā veida mērḳtiecīgs rezultāts. Procesuālā ekonomija ir ekonomiski veidota procesuālā forma (pēc principa - nekā lieka).

Nepamatoti sarežğîta procesa forma tur, kur to var aizstāt ar daudz vienkāršāku, rada lēnumu, birokrātismu, tā kavē savlaicīgu un efektīvu personas tiesību un interešu aizsardzību. Nav mazsvarīgs apstāklis, ka resursi, ko valsts var aț̣auties tērēt kriminālprocesam, ir ierobežoti, tādēl to sadales sistēma jāorganizē efektīvi.

Procesa amatpersonu pienākums, veicot procesu, ir ievērot ekonomijas principu, kas ippaši ir uzsvērts Francijas, Bosnijas, Rumānijas un citu valstu Kriminālprocesa likumos $[1,22]$. 
Jāatceras konceptuālas lietas:

1. Procesuālā ekonomija darbojas kā sava veida starpniece starp KPL mērḳi un mainīgajiem dzīves apstākḷiem.

2. Racionalitāte.

3. Nedrīkst ekonomēt uz procesuālo formu u. tml. rēḳina, radot kaitējumu saprātīgo šaubu novēršanai, personas tiesību un interešu aizsardzībai.

Tādējādi formula "vienkārši - lēti" jāpapildina ar vēl vienu elementu - personas tiesību aizsardzību. Var teikt, ka tas nav jauns, autonoms elements, bet tas norāda uz nosaukto trīs komponentu attiecīgo orientāciju. Pamatojoties uz procesuālo ekonomiju, nedrīkst pārkāpt likumā noteiktās formālās (obligātās) prasības.

Procesuālās ekonomijas būtība jāsaista, pirmkārt, ar tiesību jaunradi, formulējot KPL noteiktās normas; otrkārt, - ar racionālu darbību to piemērošanā. Procesuālo ekonomiju nevajadzētu ierobežot tikai ar likumdošanas pasākumiem. Šìs problēmas risinājumam nepietiek tikai ar kriminālprocesa racionālu procedūru, ko nosaka KPL. L,oti svarīga nozīme ir pirmstiesas procesa un tiesas iestāžu darbībai, izvēloties visoptimālāko no veicamajām procesuālajām darbībām un procesuālajiem lēmumiem, kas jāpien,em.

\section{Pētījuma rezultāti un to izvērtējums}

Tiesībās bieži atsaucas uz ekonomiju, efektivitāti un iedarbīgumu (zināmi kā trīs "E" no anglu valodas vārdiem economy, efficiency, effectiveness) [5].

Nosaucot KPL 2. nodạ̣ā ietvertās kriminālprocesu vadošās normas par kriminālprocesa pamatprincipiem, likumdevēja darbība bijusi vērsta uz visu kriminālprocesuālo kārtību vadošo normu noteikšanu. Turklāt, tā kā šo vadošo normu piemērošana īstenojama visa kriminālprocesa gaitā, secināms, ka likumā lietotais to kopējais apzīmējums - "kriminālprocesa pamatprincipi" - pilnībā atbilst kriminālprocesa tiesību zinātnes nostādnēm. Tas pats secināms arī par procesuālo ekonomiju kriminālprocesā kā kriminālprocesa pamatprincipu, jo tā nostādnes ir attiecināmas uz visām kriminālprocesa stadijām.

\section{Secinājumi un priekšlikumi}

Procesuālās ekonomijas princips veicina àtru un efektīvu noziedzīgu nodarījumu izmeklēšanu; kriminālprocesa formu racionālu diferenciāciju, mazinot birokrātiju un procesuālo pilnvaru dublēšanu; procesa virzītāju nepamatotas rīcības nepiel̦aušanu, kas varētu apgrūtināt procesa dalībniekus ar nepamatotiem pienākumiem un papildu izdevumiem. Tāpēc nepieciešamas turpmākās diskusijas, vai procesuālās ekonomijas princips jāparedz kā patstāvīgs kriminālprocesa princips vai pietiek ar pastāvošo tiesisko regulëjumu.

Autore izvirzìto mērḳi uzskatīs par sasniegtu, ja rakstā paustais viedoklis rosinās pārdomas un tālākas diskusijas par ekonomijas principa nozīmi, nepieciešamību un vietu kriminālprocesā. 


\section{Procedural Economy Principle in Criminal Proceedings}

\section{Abstract}

The article discusses the problems of principle of economy in criminal procedure law in Latvia. The paper deals with various approaches taken by economy, efficiency, effectiveness of criminal procedure. It is proposed that officials and courts not only improve but also comply with the existing legal framework when adopting objective decisions on criminal procedure.

Keywords: criminal procedure, principle, procedural economy.

\section{Literatūra un avoti}

1. Kinis, U. Krimināljurisdikcijas konfliktu jēdziens. Administratīvā un Kriminālā Justīcija, 2013, Nr. 2.

2. Latvijas Republikas Augstākās tiesas Senāta Administratìvo lietu departamenta 2010. gada 15. jünija lēmums lietā Nr. A-7-0004-10/11, S-584, 2010.

3. Satversmes tiesas 04.02.2003. spriedums lietā Nr. 2002-06-01, secinājumu daḷas 3. paragrāfs. Latvijas Republikas Satversmes tiesas spriedumi, 2002. Rīga: Tiesu namu aǵentūra, 2004, 67.-68. lpp.

4. Satversmes tiesas 30.03.2010. spriedums lietā Nr. 2009-85-01, secinājumu daḷas 20. paragräfs. Iegūts no: http://www.satv.tiesa.gov.lv/upload/spriedums_2009-85-01.htm

5. Valsts pārvaldes principi Eiropā. Iegūts no: http://www.sigmaweb.org/bylanguage/ latvian/39560292.pdf

6. Zeppa-Priedīte, V. Valsts amatpersonu Kriminālprocesuālā imunitāte Latvijas kriminālprocesa tiesībās. Iegūts no: http://www.lu.lv/fileadmin/user_upload/lu_portal/zinas/Kopsavilkums_ Zeppa-Priedite.pdf 